\title{
LA FESTA DELLA FRATELLANZA ITALIANA: \\ Gianni Grohovaz and THE Celebrations of \\ ITALIAN MEMORIal DaY IN TORONTO, 1960-1975
}

\section{Paul BaXa}

Summary: This article examines the Italian Memorial Day celebrations held in Toronto between 1960 and 1975. These celebrations were organized and conceived by poet-activist-exile Gianni Grohovaz during his tenure as director of the now defunct Italo-Canadian Recreation Club (ICRC) in Toronto. Using the Grohovaz Fonds at the National Archives of Canada, the article explores how the Memorial Day celebrations brought together Grohovaz's passions as artist and community activist. The celebrations were an attempt to fulfill the ICRC's mission of uniting Italians by transcending politics, religion, and regionalism while also allowing Grohovaz an opportunity to represent his own life as a veteran and exile from his hometown of Fiume. Through a study of Grohovaz's Memorial Day celebrations, much can be learned about the changing identity of Toronto's bourgeoning Italian community after World War II, its relations with the host and mother countries, and of the limits of trying to overcome persistent regional identities through national memory.

On 4 November 1962 at the headquarters of the Italo-Canadian Recreation Club (ICRC) at 33 Brandon Avenue in Toronto, near one of the city's Little Italies, a procession of Italian war veterans made its way from the hall onto Dufferin Street to the Church of Saint Mary of the Angels. ${ }^{1}$ This brief procession, led by a military band, and accompanying a catafalque dedicated to the Unknown Soldier, marked the anniversary of Italy's victory at the Battle of Vittorio Veneto during World War I. After a mass held at the Italianate-style church, the procession retraced its steps to Brandon Hall where the rest of the evening was spent listening to speeches by the Italian ambassador to Canada, the consul general, war veterans, and the director of the ICRC, Gianni Grohovaz. ${ }^{2}$ The evening was com-

${ }^{1}$ I wish to thank my colleagues at Ave Maria University, Gabriel Martinez and Colin Barr for their comments and suggestions on the drafts of this article. I would also like to thank Robert Buranello for providing me with a copy of Grohovaz's talk to the students of the Italian Club of Erindale College, University of Toronto.

${ }^{2}$ Grohovaz signed his name in various ways throughout his career. It appears as o 
pleted with a performance of Grohovaz's play, Il ragazzo del '99, by the Italian-Canadian theatre company Piccolo Teatro, followed by the singing of patriotic songs by the Coro Santa Cecilia.

The celebration of 3 November was the brainchild and inspiration of Grohovaz, a journalist, poet, and exile from Fiume, who had become the director of the ICRC in 1960. From 1960 to 1975 Grohovaz not only organized the Memorial Day celebrations, but also wrote and choreographed the events thus bringing together his two vocations as poet and organizer. Grohovaz's work for the celebrations was a reflection of his own life as a World War II veteran and exile from his hometown of Fiume which passed from Italy to Yugoslavia after the war. Grohovaz identified with the mission of the ICRC to unite the various Italian-Canadian associations divided along regional and generational lines. The purpose of the ICRC, founded in 1948, was to bridge the gap between the older immigrants and the new wave of immigrants who had come to Canada after the war. For Grohovaz, 4 November was an occasion which could foster a sense of solidarity among Toronto's Italians. Through his work as ICRC director, radio commentator, and newspaper editor, Grohovaz was able to promote this cause throughout the 1960s and 1970s. As this article will demonstrate, this hope was intensely personal, resulting from the events of his own life as an esule (exile).

Grohovaz as poet and writer has received some attention from scholars in recent years. ${ }^{3}$ Little has been written, however, about his work as a journalist and community activist for Toronto's Italian community. In the 4 November celebrations, Grohovaz's activities as artist and activist converged. Using the Grohovaz fonds in the National Archives of Canada, this article will examine these hitherto unexplored events held at Brandon Hall and at other locations throughout Toronto. A study of the Memorial Day celebrations will reveal not only Grohovaz's activities as a leading community figure in Toronto, but will demonstrate some of the tensions inherent in the identity formation of Italian-Canadians in the postwar period. Through Grohovaz's work on Memorial Day, issues such as the conflict between campanilismo and national identity, and the difficulties of the immigrant experience will be explored. Ultimately, the 4 November cele-

Giovanni Angelo, Giovanni, and John. This paper will use Gianni as it appears to have been the most commonly used by Grohovaz, his friends, and associates.

3 See Eisenbichler, "Il ricordo del paese natale nelle opera di scrittori giuliano-dalmati emigrati in Canada"; Eisenbichler, "Before the World Collapsed Because of the War"; Eisenbichler, "Un fiumano d'oltreoceano"; Buranello, 'Chi mai gavessi deto'. 
brations will demonstrate the limits of attempting to impose a monolithic identity on Toronto's Italians. Grohovaz was part of what Robert Harney has called the "ethnonationalist" group of Italian-Canadian intellectuals who attempted to graft a "great tradition" nationalism on Toronto's Italians and generally failed. ${ }^{4}$ As will be shown, this urgent desire from Grohovaz to search for a unity that went beyond local identities, or campanilismo, largely derived from his own experience as an esule or exile from Fiume, a city that after the war had become part of Yugoslavia.

Grohovaz's work as a poet and community activist was also shaped by the tension between his Italian patriotism and appreciation for his adopted country. In an interview given to an Italian-Canadian newspaper shortly after he was appointed director of the Ethnic Archives by the Trudeau government in 1974, Grohovaz made it clear that his work for the Italian community was central in his life: "My support for the progress of our people in this country is part of my daily response to my conscience," Grohovaz told the interviewer, Augusto Serafini. ${ }^{5}$ His work for the community was not only something he owed to fellow Italians, but also to his adopted country: "While always giving to Italy my patriotic spirit, I have given and continue to give to Canada my respect and recognition of all this country has done for me." 6 A study of the Memorial Days choreographed by Grohovaz during his time as director of the ICRC demonstrated a need to reconcile this divided loyalty. The early celebrations were characterized by an intense patriotic language which no doubt reflected Grohovaz's own experience as an esule. Over time, however, the celebrations would gradually shed the overt patriotism for a more elegiac commemoration of the dead of the two world wars. Finally, a persistent and growing theme of the celebrations was a recognition of the difficulties of the immigrant experience and of the struggles of Italian-Canadians to adapt to their adopted country. Grohovaz's Memorial Day celebrations, therefore, document the efforts of the artist and activist to explore the process of identity formation, a process that Robert Harney has recognized as a negotiation between developments in the old country and the demands of the new country. ${ }^{7}$

${ }^{4}$ Harney, "Undoing the Risorgimento," 118-119.

5 "Il mio apporto al progresso della nostra gente in questo Paese è la risposta quotidiana alla mia coscienza." National Archives of Canada (NAC), Grohovaz fonds (GF), vol. 1, file 4, Employment at the Public Archives.

6 "Pur continuando a dare all'Italia il mio spirito di Patriota, ho dato e continuo a dare al Canada il mio rispetto e la mia riconoscenza per ciò che ha fatto per me." NAC, GF, vol. 1, file 4, Employment at the Public Archives.

7 Harney, "Undoing the Risorgimento," 109. 


\section{An Exile in Canada}

Grohovaz's commitment to the Memorial Day celebrations of the ICRC grew out of his own experience as an exile. The war and the events of the postwar were the defining moments of his life. It was during this period of displacement that Grohovaz discovered his vocation as a writer. "For Grohovaz," writes Konrad Eisenbichler "writing was an obsession, something he had to do in order to respond to life and give expression to his own existence, tormented by history." 8 Grohovaz came to Canada in 1950 as a refugee, which set him apart from the vast majority of other Italian immigrants. Eisenbichler has demonstrated how this experience typically made Grohovaz and other Giuliano-Dalmati exiles more determined to demonstrate their Italianità (Italianness). After the war, thousands of Italians from Istria, Fiume, and Dalmatia fled Yugoslavia for Italy, yet they were not recognized by the Italian state. Instead, they were considered Yugoslavs. Made to live in internment camps throughout Italy, these refugees were often subjected to abuse by fellow Italians who accused them of being fascists. ${ }^{9}$

This sense of Italianità became even stronger when they emigrated to Canada. Those esuli who, like Grohovaz, arrived in Canada through the International Refugee Organization, were given manual labour jobs usually in the harsh climate of northern Ontario or in other outposts far removed from other Italian immigrants in big cities such as Toronto and Montreal. Their isolation was aggravated by the fact that the exiles did not have a hometown to return to. Robert Buranello has noted that for the Giuliano-Dalmati, home was just the memory of a "place of origin [...] frozen in time." 10 Unable to live with other Italians in Canada and unable to return to a hometown that was no longer Italian, the esuli assimilated into Canadian culture to a much higher degree than other Italians. This tendency towards assimilation was reflected by the children of the esuli who were more likely to marry non-Italians. ${ }^{11}$

Grohovaz's experiences reflected those of his fellow exiles. Before he

8 "Per Grohovaz, scrivere era un'ossessione, qualcosa che egli doveva fare per rispondere alla vita e per dare espressione alla sua stessa esistenza, travagliata dalla storia." Eisenbichler, "Il ricordo del paese natale," 102. Here and elsewhere, all translations are mine own, unless otherwise indicated.

9 Eisenbichler, "I Giuliano-Dalmati in Canada," 36.

10 Buranello, 'Chi mai gavessi deto', 139.

11 Eisenbichler, "I Giuliano-Dalmati in Canada", 40. 
had come to Canada in 1950, Grohovaz lived in various refugee camps throughout Italy, very much an exile in his own country. ${ }^{12}$ His emigration to Canada was for political, not economic reasons. Almost immediately after his arrival, Grohovaz became involved in activism on behalf of his fellow workers in northern Ontario who were often the victims of abuse from prewar Italian immigrants working as foremen. ${ }^{13}$ Although he appreciated the freedoms offered by his adoptive home, Grohovaz remained critical of the Anglo-Saxon cultural dominance of the country because it often resulted in discrimination against immigrants. According to Grohovaz, the attempt by one group to dominate others often led to totalitarianism, as it did under Mussolini's Fascism and Tito's Communism. The European experience of totalitarianism made Grohovaz wary of where discrimination could lead in Canada:

Se ci lasceranno in pace, avremo modo di fare un immenso regalo al Canada. Gli europei che sono passati per l'ignobile strada dell'oppressione totalitaria hanno molte cose da insegnare ai canadesi [...] Le nostre esperienze del passato non si imparano nelle università [...] E se il popolo canadese non capisce queste cose, abbiamo modo di pensare che il popolo canadese non è politicamente maturo. ${ }^{14}$

(If they leave us in peace, we will make a great gift to Canada. Europeans who passed along the ignoble road to totalitarian oppression have many things to teach Canadians [...] our past experiences cannot be taught in universities $[\ldots]$ and if the Canadian people do not understand these things, we then have reason to believe that the Canadian people are not politically mature.)

Grohovaz believed that his experience of living in Fiume made him sensitive to the possibility of totalitarianism. Buranello has noted that Grohovaz saw in Canada a similar patchwork of diverse people as existed in Fiume before the war. Although Toronto and Fiume looked very different as cities, they were both examples of how different ethnic groups could peacefully co-exist. ${ }^{15}$

12 These refugee camps included Fertilia dei Giuliani in Sardinia. This half-finished town, begun in the 1930s under Mussolini's bonifica program, was colonized by a group of esuli led by Don Francesco Dapiran immediately after the war. Grohovaz was among the first group of settlers. The story of his short time in these camps is told in Grohovaz, Strada bianca, 41-46.

13 MS Grohovaz, "Rimestando tra le acque del passato."

14 NAC, GF, vol. 1, file 6, Editorials for CHIN.

15 Buranello. ' Chi mai gavessi deto,' 148. 


\section{Patriotism and the Festival of Italian Brotherhood}

"As you know," wrote Gianni Grohovaz to the head of Toronto's Alpini Association in 1974 "one of the most important aims of my life is to unite Italians." 16 With this ambitious statement, Grohovaz defined much of his life and career since arriving in Canada in December 1950. Before becoming director of the ICRC in 1960, Grohovaz had already demonstrated this ambition as chief editorial writer for the fledgling Corriere Canadese, an immigrant newspaper he had helped establish with Arturo Scotti in 1954. ${ }^{17}$ As editor, Grohovaz became well known as a champion of ItalianCanadian construction workers who faced discrimination and dangerous working conditions, notably after the Hogg's Hollow tragedy in $1960 .{ }^{18}$ As director of the ICRC, Grohovaz was given the means to unite the various regional associations to which Italian-Canadians belonged.

Bringing together these disparate associations was the raison d'être of the ICRC. Founded in 1947 by a group of prewar Italian immigrants, the ICRC aimed to unite all Italian-Canadians from every regional and political background, especially the flood of immigrants who had come to Toronto in the years after World War II. This task was made difficult by the political divisions caused during the fascist years when, through the offices of the Consulate, the Italian regime attempted to impose an ideological unity on Toronto's Italians. ${ }^{19}$ The fact that the new arrivals generally abstained from joining prewar associations also did not help. ${ }^{20}$ They preferred, instead, to join new regional associations which blossomed in the 1950 s and 1960s. ${ }^{21}$ In order to overcome these political divisions, the founders of the ICRC insisted that the organization be apolitical and secular. In 1948, to facilitate this new era of common cause, a meeting hall was built at 33 Brandon Avenue in Toronto, in the Dufferin and Davenport section of Toronto, one of four major settlements of Toronto's Italians. ${ }^{22}$ The site, known simply as Brandon Hall, became the central place where the dif-

16 "Come lei sa, uno dei più importanti scopi della mia vita, è quello di unire gli italiani." NAC, GF, vol. 1, file 21, Correspondence sent and received.

17 Grohovaz, "Toronto's Italian Press after the Second World War," 108-109.

18 Iacovetta, Such Hardworking People, 170.

19 See Zucchi, Italians in Toronto, chapt. 7.

20 Zucchi, Italians in Toronto, 142.

21 Zucchi, "Cultural Constructs or Organic Evolution?" 31.

22 Zucchi, Italians in Toronto, 41. 
ferent clubs could meet and where the apolitical and secular mandate of the ICRC would be respected. It also became a place of socializing and a site of celebrations hosting, according to Grohovaz, a majority of the Italian community's wedding receptions. ${ }^{23}$ Trophies and standards were kept there, as were archives documenting the growth of the community.

Brandon Hall represented everything that Grohovaz believed in. It was there that solidarity among Italians and fidelity to Italy could be practiced without the disruptions of party politics and religion. Such intrusions proved difficult to prevent however. Before Grohovaz assumed the directorship, an incident over a gold crucifix, a gift from the Archdiocese of Toronto, caused a storm among some of Brandon's groups, especially those who wanted to preserve the secular character of the ICRC. ${ }^{24}$ In Grohovaz's first year as ICRC director, Brandon Hall became the site of the first attempts to form Italo-Canadian trade unions. Grohovaz supported unionization, but he was troubled by the overt use of communist propaganda at the first meetings, which he denounced in his editorials for the Corriere Canadese. ${ }^{25}$ These dangers to the mission of the ICRC convinced Grohovaz that some celebration of Italian unity was needed which transcended politics and religion. Not long after becoming director, Grohovaz was approached by several Italian clubs led by the Club Sanquirinese (a Friulian association) to host a Memorial Day celebration in honour of Italy's victory at the Battle of Vittorio Veneto in 1918. ${ }^{26}$ Years later, Grohovaz claimed that these groups were working together "towards a unified community spirit." 27 In a letter to the Italian Ambassador to Canada, thanking him for attending the 1961 celebrations, Grohovaz stated the fundamental task of 4 November was to be a "double manifestation of Italianness and brother-

23 The building was sold in 1980. In a scathing radio editorial broadcast just after the sale, Grohovaz expressed his anger and shame at the Italian community for not doing more to keep the hall. He was especially mortified that none of the belongings of the hall or the archives of the ICRC had been kept. Grohovaz, ...e con rispetto parlando, 143-145.

24 Grohovaz, "See You at Brandon Hall," 102.

25 Iacovetta, Such Hardworking People, 170.

26 Grohovaz came to rely substantially on Friulian associations and groups in his celebrations like the Famee Furlane and the Coro Santa Cecilia. This is not surprising as Friuli was a region that had experienced the First World War directly. Also, a majority of Toronto's Friulani lived in the Dufferin and Davenport neighbourhood in the 1960s. See Zucchi, Italians in Toronto, 57-58.

27 Grohovaz, Coro Santa Cecilia, 12. 
hood shared by our co-nationals who live here."28 Grohovaz was convinced that the Memorial Day celebrations were the key to cementing closer ties between the various Italian regionalist groups:

Il 4 novembre rimarrà per gli Italiani di Toronto la base delle future relazioni fra le Associazioni Italiane, che sotto il Suo onorato patrocinio, oggi incominciano una nuova era di reciproca comprensione nello slancio commune a risolvere quei problem di scottante attualità che ci circondano e a mantenere sempre più alto il prestigio degli Italiani all'estero. ${ }^{29}$

(The fourth of November will remain for Toronto's Italians the basis for future relations between the different Italian Associations, who under the guidance of your honoured patronage, begin today a new era of reciprocal comprehension in the common effort to resolve those problems which surround us and to maintain a high level of prestige among Italian immigrants.)

Never one to indulge in false modesty, Grohovaz took pride in the celebrations. In a letter to the Italo-Canadian associations which participated in the 1961 event Grohovaz wrote the following: "Many have said, with good reason that the second edition of the Celebration of 4 November will remain in the annals of Toronto's Italian community, as the most beautiful affirmation of our Colony in this land." 30 Grohovaz's strong belief in the significance of the event was confirmed by his enlisting of what he considered to be the best representatives of Italianità among the immigrant associations. These included the Piccolo Teatro, founded by a former ICRC director Bruno Mesaglio, to perform the plays. According to Grohovaz, this company of actors represented those newer Italian immigrants who "were not embarrassed by their Italianness."31 For the music, Grohovaz relied on the Coro Santa Cecilia conducted by another Friulian, Lino Springolo. Grohovaz later claimed that this choir was born during an impromptu session at the first Memorial Day celebrations in 1960.32

28 "Una duplice manifestazione d'italianità e fratellanza fra i connazionali qui residenti.” NAC, GF, Vol. 2, Associazione Nazionale Alpini.

29 NAC, GF, Vol. 2, Associazione Nazionale Alpini.

30 "Molti hanno detto, e con ragione, che la II Edizione della Celebrazione del 4 Novembre, rimarrà negli annali della storia degli italiani a Toronto, come la più bella affermazione della nostra Colonia in questa terra." NAC, GF, Vol. 2, Associazione Nazionale Alpini.

31 Grohovaz, "A Quest for Heritage," 47.

32 Friulian associations were preponderant in the 4 November celebrations; they 
Most of all, Grohovaz viewed the veterans associations as the best vehicles for promoting national unity. Disillusioned by the party politics of postwar Italy, Grohovaz saw the veterans groups as embodying a sense of patriotism that transcended politics. Part of this belief was personal, deriving from Grohovaz's own service in the military and from his hope that Fiume would one day be reclaimed by Italy. Grohovaz expressed this view especially among other Fiuman exiles whom he advised to cultivate relationships with military associations as a means of keeping the "culto di Fiume" alive. 33 Grohovaz's belief in the veterans groups figured prominently in his Memorial Day commemorations right from the beginning. This was especially true of the Associazione Nazionale degli Alpini (ANA), of which Grohovaz was a member. The penne nere, as the Alpini are often called, are one of the most famous regiments in the Italian army, known for their esprit de corps, fighting record, and most of all their canti (songs). In his autobiographical novel, Strada bianca, Grohovaz remembered his encounter with the legend of the Alpini as a schoolboy; a personal experience which he considered universal for all Italian children in the 1930s:

Provate a pensare a quando andavamo a scuola e la maestra, durante l'ora di storia (sono certo che succedeva anche nella vostra classe) si alzava in piedi e con voce commossa ci leggeva il bollettino della Vittoria del 4 Novembre ... Ditemi? Il vostro pensiero a chi volava? A tutti i soldati, d'accordo. Ma nella nostra mente di ragazzini come ci raffiguravamo questi uomini eroici? Ma con la penna nera, sicuramente! ${ }^{34}$

(Try to remember when we all went to school and the teacher during the hour of history instruction (I'm certain that this happened in your classes) would rise to her feet and with a voice brimming with emotion would read to us the bollettino della Vittoria del 4 Novembre ... Tell me? What did you immediately think of? Of all the soldiers, of course. But in our youthful minds, how did we picture these heroes? With the penna nera of course!)

Grohovaz's experience was a reflection of the disproportionate influence Alpini writers had on the military memory of Italy especially before

included the Famee Furlane Club of Toronto, the Club Sanquirinese, and the Azzanese Club. Grohovaz noted the irony that one of Italy's most "separatist" regions provided such important contributions to this manifestation of Italian patriotism. See Grohovaz, "See You at Brandon Hall," 99.

33 NAC, GF, vol. 1, no. 12, Correspondence about his book.

34 Grohovaz, Strada Bianca, 73. 
World War II. ${ }^{35}$ Many of the motifs of Alpini writing would find their way into Grohovaz's 4 November plays, such as the exaltation of the common soldier (fante) and the shared rigours of military service (naja). ${ }^{36}$ The forging of brotherhood in the trenches and devotion to the memory of lost comrades, themes which permeate Grohovaz's 4 November ceremonies, were also leitmotifs in the writings of the Alpini.

For Grohovaz, the ANA was a privileged site where Italian solidarity and fidelity could be cultivated. Grohovaz's feelings on this issue substantiate Harney's thesis that the experience of Toronto's Italian community cannot be separated from developments in Italy. ${ }^{37}$ In Grohovaz's mind, advocacy for Toronto's Italians was closely related to sentiment for the home country. This is noted in a letter he wrote to a Lt. Col. Delfino just after the first 4 November celebrations in 1960. In this letter, Grohovaz describes the joy he felt at unpacking the Alpini cap with the black feather sent to him by Delfino: "You cannot imagine what I felt when I opened the package you sent me ... that cap with the long black feather and the medallion of the Third Regiment will one day be passed on to my son."38 At the end of the letter, Grohovaz pledges both his and Italians immigrants' readiness in case the patria should need them again. Significantly, Grohovaz also described his work for the Corriere Canadese as an act of patriotism in the service of Italian immigrants. For Grohovaz, these personal and professional aspirations found their ultimate expression in the Memorial Day celebration which had just concluded: "A few hours have passed since the reception, and even now as I write these lines a shiver of pride courses through my veins." 39

\section{Isnenghi, Il mito della Grande Guerra, 343-344.}

36 The term naja was applicable to all the units in the Italian army but, as Gianni Oliva argues, "il modello destinato ad incidere più profondamente nell'immaginario collettivo, per la sua capacità di aderire al sentire commune della popolazione cui si rivolgeva, era tuttavia l'alpino." The naja as symbolic of the popular experience of the Great War can be attributed to the Associazione Nazionale Alpini and the writings of Alpini veterans like Pietro Jahier. See Oliva, "La Naja," 104-105.

37 Harney, "Undoing the Risorgimento," 109.

38 "Lei non puo immaginare che cosa ho provato nell'aprire il pacchetto da Lei inviatomi ... quel cappello dalla lunga penna nera ed il fregio del Terzo passerà in eredità a mio figlio.” NAC, GF, vol. 2, Associazione Nazionale Alpini.

39 "È passata qualche ora dalla ricezione, ed anche adesso mentre scrivo queste righe un brivido di orgoglio mi serpeggia nelle vene." NAC, GF, vol. 2, Associazione Nazionale Alpini. 
Grohovaz's commitment to the Alpini and to the memory of the Great War was a product of his own traumatic experiences in World War II. In Strada bianca, Grohovaz described his experience in the war as one of pain and confusion not just for himself but also for all Italians after Italy's surrender to the Allies on 8 September 1943. This date marked Italy's descent into civil war causing what one historian has called the most serious crisis in the history of united Italy.40 "Bufera", a poem written by Grohovaz and included in a collection of his poetry in Fiuman dialect, viewed 8 September as the beginning of Fiume's troubles. ${ }^{41}$

After 8 September, the Alpini, like the rest of the Italian armed forces, fell into disarray. The monarchy fled to the south while German forces invaded from the north occupying most of Italy including Fiume. Some of the Alpini battalions, remaining loyal to the king, went to serve with the Allies in the south; others disbanded and helped the partisans in the north while others became part of Mussolini's Italian Social Republic, also known as the Republic of Salò. Still others, like Grohovaz's Julia battalion, stayed on the Yugoslav frontier and fought alongside the Germans against the communist partisans of Marshal Tito. One particular episode which Grohovaz recounts in Strada bianca embodies the dilemma of Grohovaz's battalion when it was confronted by what seemed like an enemy plane:

Un aereo solitario gironzolò per un pezzo ad una discrete altitudine. Si trattava di un Macchi 202. Quando si avvicinò a volo radente la mitragliera era lì ad attenderlo, però non sparò: sulle ali c'erano dipinti i colori italiani e sul bianco c'era lo stemma del Re. Erano fratelli anche se combattevano al Sud e poi, gli alpini anche se facevano parte dell'Esercito regolare dell'Italia senza stemma, non potevano dimenticare il monarca perduta. ${ }^{42}$

(A solitary airplane circled over us for a while at a discreet altitude. It was a Macchi 202. When it came closer our machine gun was waiting for it, but it didn't fire: on the wings of the plane were visible the colours of Italy and on the white section was the king's coat of arms. They were brothers even if they fought for the South. The Alpini, although they were part of the Italian army without the coat of arms, could not easily forget their lost king.)

40 Franzinelli, "L'8 settembre," 244.

41 "Quando pareva che tuto era finido / (dopo la firma l'oto de setembre) / a Fiume nove gnochi [Germans] xe arivadi / e con un panzer i ne ga "libera" Grohovaz, "Bufera" in Grohovaz, Per ricordar le cose che ricordo, 15.

42 Grohovaz, Strada bianca, 77. 
What happened next shocked Grohovaz and his fellow soldiers: "Yet, even if our own troops refused to fire, the pilot of the airplane didn't hesitate to vomit fire on us." 43 Tellingly, the commander who ordered that his battalion not fire on the plane was a Great War veteran. Faced with the confusion of World War II, confusion Grohovaz's own battalion contributed to with its decision to fight on the side of the Germans, Grohovaz developed a romanticized view of the previous war. It was this view which shaped his 4 November productions.

The early editions of the Memorial Day celebrations were composed in a strongly patriotic key. The first celebration in 1960 concluded with a reading of General Armando Diaz's victory bulletin issued after the Battle of Vittorio Veneto in 1918. ${ }^{44}$ The early celebrations also included references to the terre irredente as the cause for which the war was fought. The 1963 presentation, for example, used the voice of a soldier who had died fighting for the "unredeemed" territory that had now been lost after World War II: "Down there is the land for which we died / and now the Patria has lost it once again / Venezia Giulia, Holy Gorizia, Saint Pola, Fiume Olocausta / and you, Italian cities, is our sacrifice not worth anything?" 45 Those earlier celebrations also made references to specific battles and places of the war such as Cima 118, Monte Pasubio, Monte Grappa, and Redipuglia, names found in the pantheon of Italian patriotic sentiment.

Images like Fiume Olocausta could be traced to one of Grohovaz's idols, the poet-soldier Gabriele D'Annunzio, who in 1919 led an armed expedition of World War I veterans to Fiume in order to claim it for Italy. D’Annunzio and his legionnaires occupied Grohovaz's native city for over a year until they were chased out by Italian gunships. D'Annunzio's legend cast a long shadow over the Fiume in which Grohovaz grew up, and the

43 "Ma se la nostra arma non aprì il fuoco, quella dell'aereo non si fece pregare due volte e vomitò a lungo lingue di fiamme." Grohovaz, Strada bianca, 77.

44 Diaz's Bolletino concluded the Memorial Day ceremonies and reads as follows: "La Guerra contro l'Austria-Ungheria che, sotto la guida di sua Maestà il ReDuce Supremo-l'esercito italiano, inferiore di numero e per mezzi, iniziò il 24 maggio 1915 e con fede incrollabile e tenace valore condusse ininterrotta ed asprissima per 41 mesi, è vinta. I resti di quello che fu uno dei più potenti eserciti del mondo risalgono in disordine e senza speranza le valli che avevano disceso con orgogliosa sicurezza. 4 novembre 1918. Armando Diaz.” NAC, GF, vol. 1, file 18 , Il ragazzo del ' 99 .

45 "Laggiù la terra per la qual morimmo / ed ora la Patria l'ha perduta ancora / Venezia Giulia, Gorizia Santa, Pola, Fiume Olocausta / E voi tutte le Italiche sorelle a nulla valse il nostro sacrificio?" NAC, GF, vol. 1, file 18, Il ragazzo del '99. 
memory of that episode remained strong especially after Fiume became part of Yugoslavia in the wake of World War II. 46 Grohovaz effectively celebrated D'Annunzio's legacy by appropriating the poet's language and imagery in the Memorial Day celebrations, especially in those of the early 1960s.

A recurring motif in Grohovaz's commemorations was the image of Italian soldiers leaving their towns and regions to fight for Italy, something that Grohovaz used as an analogy for the immigration experience. Borrowing Alpini idioms, Grohovaz spoke of the "great little men" who left their homes in all regions of Italy, embarked on the troop trains in Verona, and headed for the front. ${ }^{47}$ In some ways, this migration of young men prefigured the mass emigration of Italians to the New World after World War II. Grohovaz saw this sense of united purpose as an important lesson for Toronto's Italian-Canadian community and he never tired of repeating it during the celebrations. For example, Grohovaz opened one of the commemorations in the early 1970s with the following statement: "We have always said and continue to say that November 4th is the festival of Italian brotherhood whether they are from the north or the south because we are Italians above all else." 48 During the 1969 celebrations Grohovaz repeated that 4 November was the "festival of Italian brotherhood [...] today we feel united as brothers without any local distinctions, from the Alps to Sicily, brothers in the name of God and of the Patria." 49

Grohovaz's insistence on the idea of festa della fratellanza di tutti gli italiani was due to the increasing number of regionalist associations emerging in the late 1960s and to the changing settlement patterns of Toronto's Italian community. 50 As the population of immigrants settled and accumulated savings, Toronto's Italians moved to the new subdivisions in the northwest and northeast of the city away from the historic settlements in

46 The Grohovaz fonds in the National Archives include a file on the commemoration of D'Annunzio's occupation of Fiume.

47 NAC, GF, vol. 1, file 17, Il dono del vecchio soldato.

48 "Il 4 novembre l'abbiamo detto e lo ripetiamo è la festa della fratellanza fra gli italiani siano essi del nord o del sud perchè siamo sopratutto italiani." NAC, GF, vol. 2, Associazione Nazionale Alpini

49 "Il quattro di novembre e la festa della fratellanza di tutti gli italiani qui residenti ... in questa giornata ci sentiamo tutti uniti, tutti fratelli, senza distinzione di provenienza, dalle Alpi alla Sicilia, fratelli nel nome di Dio e della Patria." NAC, GF, vol. 1, Il dono del vecchio soldato.

50 Zucchi, "Cultural Constructs or Organic Evolution? Italian Immigrant Settlements in Ontario," 31. See also Iacovetta, Such Hardworking People, 152. 
or near downtown Toronto. ${ }^{51}$ In order to keep the 4 November celebrations strong, from the late 1960s Grohovaz began taking the event to the new neighbourhoods. Leaving Brandon Hall behind, the celebrations now took place in parish halls across the city.

Grohovaz's determination to bring the 4 November celebrations to Italians as they moved into new neighbourhoods in the early 1970s was made urgent by his fear that the community was losing its always fragile cohesiveness. He used his frequent radio editorials on CHIN (Toronto's multicultural radio station founded by Johnny Lombardi) to chastise the community for failing to unite on important issues. In one exasperated example in September 1972, Grohovaz exclaimed: "Unity. What a difficult word in the Italian vocabulary!"52 Painfully, Grohovaz also noticed that veterans' associations such as the Alpini were not immune from the regional prejudices that continued to afflict Italians. In February 1974, Grohovaz and his wife, Lisa Paradiso, attended the annual Alpini dance and were mortified to hear anti-Southern slurs from the other guests. Not only was this personally offensive, as Mrs. Grohovaz was from the South, but it also shattered Grohovaz's illusions about the ANA: "During the course of your last social," wrote Grohovaz the following day to Attilio Paron, President of Toronto's Alpini Association "I noticed that certain values of national integrity which should be at home in the veterans' associations, are instead defiled to the point of personal insult." 53 For Grohovaz, there was no place in the veterans' associations for campanilismo, but only for patriotism.

\section{Memorial Day and the Italian-Canadian Community}

In an effort to counter the regionalist tendencies of Toronto's Italians,

51 As a journalist, Grohovaz was always concerned that some of Toronto's Italians were being ignored when they moved to suburbs like Scarborough. He accused Italian-Canadian newspapers such as the Corriere Canadese of failing to announce community events or solicit the views of those who chose to live far away from the historic settlements. Grohovaz tried to correct this through his CHIN radio editorials and as editor-in-chief of Il Giornale di Toronto. Grohovaz, “Toronto's Italian Press," 113.

52 "Unità. Che parola difficile nel vocabolario italiano!" NAC, GF, vol. 1, file 6, Editorials to CHIN.

53 "Nel corso del vostro ultimo ballo sociale ho avuto modo di esperimentare che certi valori di integrità nazionale che dovrebbero trovare posto proprio nelle associazioni d'arma, vengono invece deturpati fino al punto di giungere all'offesa personale." NAC, GF, vol. 1, file 21, Correspondence sent and received. 
Grohovaz hoped that the 4 November celebrations would at least maintain the Italian-Canadian community's ties to the mother country. Ironically, as Harney has demonstrated, it was the Italian government which most contributed to the growth of regionalist identity in the 1970s after its creation of regional governments. ${ }^{54}$ Despite this, Grohovaz still hoped that the uniformed services in Italy would be bulwarks of Italian unity. In 1973 Grohovaz wrote a letter to the Italian Minister of Defence, Mario Tanassi, expressing the hope that his televised play, Il ragazzo del '99, would be transmitted by RAI-TV in Italy on Memorial Day and then distributed to Italian veterans' associations around the world. In the letter, Grohovaz describes his work among Italian immigrants and his hopes for what 4 November will do for them: "A date which can unify them, at least for one day a year, in thought and in action". 55 After describing his work with the Memorial Day celebrations in Toronto, Grohovaz concluded the letter by expressing his hopes that Italy would be convinced by the continuing loyalty of its expatriates:

La mia potrebbe essere definita una ambizione personale, ma in definitivo altro non è se non il desiderio di poter dimostrare alla Patria che gli italiani in Canada non dimenticano la terra che diede loro $i$ natali. Vivendo anche all'estero le pagine più belle della nostra storia diamo ai nostri figli ed ai nostri ospiti, un ampio quadro della nostra umanità e del nostro retaggio. 56

(My ambition is a personal one, but it is the desire to demonstrate to Italy that the Italians in Canada will never forget their homeland. Even though we live elsewhere we still give to our children and hosts the best pages of our national history which includes a full picture of our humanity and our heritage.)

Grohovaz explained this ambizione personale as the result of his being a "refugee from Fiume who has always held high the ideal of the Patria for which, in the last war, he contributed a modest service." 57 The intersection

54 Harney, "Undoing the Risorgimento," 113.

55 "Una data per unificarli, almeno una volta all'anno, con il pensiero e l'azione." NAC, GF, vol. 1, file 6, Editorials to CHIN.

56 NAC, GF, vol. 1, file 6, Editorials to CHIN.

57 "Sono un profugo da Fiume [who has] mantenuto sempre alto l'ideale della Patria per la quale, nell'ultimo conflitto ho prestato la modesta opera." NAC, GF, vol. 1, file 6, Editorials to CHIN. 
of the personal and professional, so important to an understanding of Grohovaz's life and work, is made clear in this letter to the representative of Italy's armed forces. Grohovaz's identity as an exile from his own country is indispensable for an understanding of his patriotism and of his desire to demonstrate his own loyalty to Italy, as well as that of his fellow immigrants in Canada.

Grohovaz expressed this personal mission in his 4 November celebrations. From the beginning, the Memorial Day productions were a platform for highlighting the links between Italy and her expatriates. A key part of the celebrations was the participation of Italian officials such as the Ambassador and Consul General, and the distribution of medals such as the Order of the Knights of Vittorio Veneto. Beginning in the 1950s, this medal was awarded by the Italian government to veterans of the Great War. It was a belated recognition, a fact ironically commented upon by Grohovaz in several of his Memorial Day celebrations especially in Il dono del vecchio soldato, yet Grohovaz made sure to keep a list of World War I veterans living in Toronto so that no soldier would be forgotten. 58

The high point of this unity between Italian-Canadians in Toronto and Italy came during the 1972 Memorial Day celebrations which coincided with Alitalia's first direct flight from Rome to Toronto. Grohovaz proclaimed the coincidence of these two events as a great moment of Italianità. He had been involved in lobbying Alitalia to start a Toronto service in recognition of the fact that the Ontario capital had surpassed Montreal as the Canadian city with the largest Italian population. On board the flight was the marching band of the Carabinieri, Italy's national police, who would tour Canada. For Grohovaz, the Carabinieri represented another uniformed association that embodied Italian unity and so he wasted no time in having them perform at the Memorial Day celebrations held that year in the Garden Room of the Royal York Hotel in Toronto.

As always, Grohovaz used the occasion to proclaim his patriotism, telling the Carabinieri that once they return home they should bear witness to the fidelity of the Italian immigrants. In a speech designed to prove the fidelity of Toronto's Italians to the home country, Grohovaz urged the Carabinieri to render homage to the Tomb of the Unknown Soldier in Rome on behalf of Italian immigrants: "We immigrants are simple people; we are people who become emotional before the flag, people who palpitate

58 One such example from 1970, containing sixteen names and addresses, is found in the Grohovaz fonds. NAC, GF, vol. 3, Italo-Canadian Club Veterans' Day Ceremonies. 
with a great faith when the Patria is represented by something great and sublime like the uniforms of the armed services." 59 This very patriotic speech, laden with references to the Great War, was reminiscent of the D'Annunzian tone of the early Brandon Hall celebrations, but its focus was less on the war and more on the immigrant experience.

The 1972 celebrations proved an occasion to mark the ties between Canada's Italians and Italy, but it also provided an opportunity for Grohovaz to demonstrate the community's place in Canada's evolving multicultural scene. Now in Canada for over twenty years, Grohovaz increasingly thought about the integration of the Italians into Canada, a fact made more interesting by the Canadian government's official policy of multiculturalism, instituted in 1971. In his CHIN radio announcement of the 1972 commemorations, Grohovaz exhorted Italian-Canadians to profit from this: "We have an opportunity to show our Canadian hosts that the Italian community is united in solidarity and above all that we do not forget our past and we know how to be at the same time good Italians and good Canadians." 60 It was this goal, of being good Italians and good Canadians, which increasingly became the leitmotif of the Memorial Day celebrations in the 1970s.

\section{The Immigrant Experience}

The immigrant experience in Canada had always been present in Grohovaz's Memorial Day observations though not always their main focus. By 1975, however, the last of the Grohovaz productions for Memorial Day, the relationship between Italian immigrants and their Canadian hosts had become the central theme. The early 4 November celebrations saw immigration as a painful experience which sent Italians far away from their homeland. As previously mentioned, Grohovaz equated emigration with leaving home for the front. In the 1963 Memorial Day presentation, Grohovaz made this theme explicit from the beginning. With the Coro Santa Cecilia singing the Friulian emigrant song, "Lontan, Lontan" in the background, the narrator linked the immigrant experience

59"Siamo gente semplice, noi emigranti; gente che si commuove davanti al vessìllo tricolore, gente che palpitò di una grande fede quando la Patria è rappresentato da qualche cosa grande e sublime come l'uniforme del'Arma benemeriti." NAC, GF, vol. 1, file 7, Editorials to CHIN.

60 "Abbiamo una buona occasione per fare vedere ai nostri ospiti canadesi che la Comunità italiana è unita e solidale e sopratutto, che non dimentichiamo il nostro passato è sappiamo essere nel medesimo tempo dei buoni italiani e dei buoni canadesi." NAC, GF, vol. 1, file 7, Editorials to CHIN. 
with that of the war:

Emigranti ... giovani e vecchi siamo andati lontano ... attraverso gli immensi mari per cercare nuovi lidi, cose nuove, conoscere gente diverse, imparare lingue straniere ... Abbiamo lasciato le italiche sponde per zappare suolo forestiero, per guadagnarci un pane diverso ... Ed ecco che una giornata memorabile nella storia d'Italia ci riunisce: SIAMO TUTTI FRATELLI [the emphasis is Grohovaz's] ... Che importa se Giorgio è nato a Venezia, Filippo è di Roma, Giancarlo di Bari o Francesco di Nuoro? Dalla Sicilia alla Vetta d'Italia il 4 Novembre siamo solo italiani. Ed il 4 Novembre ci porta lontano. ${ }^{61}$

(Emigrants ... young and old we went far ... we crossed the immense oceans to search for new beaches, new things, to get to know different peoples, learn strange languages ... we have left the Italic coasts to till foreign soil, to earn a different bread ... and yet here is a day which has historically united us: WE ARE ALL BROTHERS ... What does it matter if Giorgio was born in Venice, if Filippo is from Rome, Giancarlo from Bari or Francesco from Nuoro? Whether from Sicily or the top of Italy on 4 November we are all Italians.)

The immigrant experience, like the war, served to unite Italians. In $I l$ ragazzo del '99, performed at the 1962 commemorations by Bruno Mesaglio's Piccolo Teatro, the three old soldiers in the first scene are immigrants. They had fought together in an Alpini regiment during the war and now they are old men who convene once a year, on 4 November, to remember a fallen comrade named Michele. Their memory of Michele is elegiac, symbolizing what they have lost. He was not only a comrade and friend, but he also represents the Italy of their youth, from which they are now alienated. Their new home, Canada, offers little solace, although the old men are amazed that they can still gather to celebrate Memorial Day: "It's incredible, especially in this country where spiritual values count for little," laments one of the characters. ${ }^{62}$ They are nostalgic for their youth, even if it was spent in the trenches where they lost friends and limbs: "Yes it's true they were different times," says one of them "but why such a difference between then and now? Slavery to the dollar is killing the new generation, and with the poetry of life taken away, what else is left to man?"63

\section{NAC, GF, vol. 2, Associazione Nazionale degli Alpini.}

62 "È da meravigliarsi proprio, specialmente in questo paese dove tutti i valori dello spirito contano tanto poco." NAC, GF, vol. 1, file 18, Il ragazzo del '99.

63 "Sì, erano altri tempi è vero, ma perchè tanta differenza? La schiavitù del dollaro sta ammazzando la nuova generazione e, tolta la poesia della vita, che altro rimane all'uomo?" NAC, GF, vol. 1, file 18, Il ragazzo del '99. 
Despite these criticisms of their adopted country, which they see as materialistic, the old soldiers realize that being in Canada has brought some unexpected blessings. Speaking of their company commander, Giacomo, for whom they are waiting, one of the soldiers realizes that he is better off in Canada than back in Italy: "What would Giacomo say since he was left with nothing? If his son didn't call him to Canada he would be in an Italian nursing home good for nothing! Blind in one eye and missing an arm what could he do? Beg for alms?" 64

The play concludes with a flashback to the events that led to Michele's death. Before he dies in the trench, after crawling back from No Man's Land where he was shot, Michele asks that a letter from his mother be read to him by the chaplain. In the letter, the mother praises her son for doing his duty just as his father, killed earlier in the war, had done. She admonishes the imboscati (shirkers) who had stayed home while others died in the trenches. Typically for Grohovaz's early Memorial Day events, the play ends in a patriotic key, but it contains a hint of the immigrants' acceptance of Canada as their new home that would be developed in later commemorations.

In 1965, Grohovaz presented his second play, Il dono del vecchio soldato, at Brandon Hall. The story is similar to Il ragazzo - on 4 November an old soldier who is also an immigrant pays tribute to a fallen comrade Franco. Unable to visit the grave of his frfiend in Italy, the veteran visits instead a Canadian cemetery where he stops at the grave of a Canadian soldier with the very Anglo-Saxon name of Tom Smith. ${ }^{65}$ He asks Smith pardon for using him as a substitute for Franco and justifies himself by telling him, "unlike we the living, you the dead are all equal." 66

As in Il ragazzo, the veteran rues the day he came to this land "which doesn't speak to me." $67 \mathrm{He}$ tells Franco/Smith that he was lucky to die in the war and not face the fregature (rip-offs) that returning soldiers endured when they came back home. In an autobiographical moment, Grohovaz

64 "Che cosa dovrebbe dire Giacomo che non gli è rimasto nulla? Se suo figlio non l'avesse chiamato in Canada a quest'ora sarebbe in Italia in un ospizio per vecchi buoni a nulla! Cieco d'un occhio e senza un braccio cosa potrebbe fare? Chiedere l'elemosina?" NAC, GF, vol. 1, file 18, Il ragazzo del '99.

65 In the script found in the archives, the name was left out and then added in by hand. NAC, GF, vol. 1, file 17, Il dono del vecchio soldato.

66 "Voi morti siete tutti uguali, mica come noi." NAC, GF, vol. 1, file 17, Il dono del vecchio soldato.

67 "In questa terra che non mi dice nulla." NAC, GF, vol. 1, file 17, Il dono del vecchio soldato. 
has the veteran complain that he was beaten up for trying to save Italy. 68 Not only did returning soldiers suffer indignities, but the Italian state also lied to them, telling soldiers that this would be the last war when in fact it would give rise to another more terrible war. Thus, although the sense of alienation in a new land remains in this play, there is also a more critical stance toward Italy. The overtly patriotic tones of Il ragazzo are missing and more universal ideas are expressed, such as unity in death, loss of innocence, incommunicability between generations, and shared sacrifice. Whereas Il ragazzo concludes with Michele's mother's patriotic exhortation, and some of the earlier Memorial Day celebrations ended with Diaz's Bolletino della Vittoria, Il dono concludes with the old veteran leaving the cemetery in silence.

Gradually, Grohovaz's Memorial Day celebrations moved away from irredentism to focus on the dead. In this way, Grohovaz was imitating the message advanced by most war memorials in Italy; less a remembrance of the specific issues which led to war and more a recollection of the sacrifices made by soldiers. According to Mario Isnenghi, these monuments in Italy "represent the peace brought on by death, they ask for veneration and silence_-and an end to discussions and divisions over what happened."69 Remembering the war in this fashion also brought the Memorial Day commemorations closer to the Canadian style of remembrance where local monuments mainly focused on the sacrifice of young men and not on specific issues of the war. ${ }^{70}$ The convergence of Italian and Canadian ways of

68 A year before he died, Grohovaz granted an interview to a fellow Fiuman writer Claudio Antonelli in which he recounted his experience as a prisoner of war. $\mathrm{He}$ told Antonelli of being beaten up by the Partisans because he insisted on calling himself Italian despite his Slavic sounding name: "E ogni volta io gli tornavo a dire: sono fiumano, sono Italiano! Cos'altro avrei dovuto rispondere? Se ero italiano ero italiano!" Antonelli, Fedeli all'Istria, 86.

69 "Questi monumenti rappresentano infatti la pace della morte, chiedono venerazione e silenzio - e non più discussioni e divisioni sull'accaduto." Isnenghi, "La Grande Guerra," 301.

70 The idea behind many Canadian monuments is perhaps best expressed by the Canadian writer Pierre Berton in a forward for a book on Canadian war monuments: "The names of the dead stand for the sacrifice as well as the futility of war - tens of thousands of them spread across the country engraved on sullen bronze. Here you can sense the lifeblood of the nation draining away, the flower of our youth scythed down, the promise of the future distorted. As this book suggests, 'War Memorial' is the wrong word; 'Peace Memorial' serves us better." Shipley, To Mark Our Place, 8. The Canadian approach to remembering the 
remembering World War I can be seen in the actions of the old soldier who, though regretting that he's not in Italy, finds solace in speaking with the dead Canadian soldier. Not only does he give his medal to Smith/Franco, since it means nothing to his children and grandchildren, but he also pours wine on the grave in an act of communion.

Il dono pointed to new directions in Grohovaz's Memorial Day commemorations-World War I was seen less as a moment in nation building and patriotism and more as a tragedy. Gradually, Grohovaz's Memorial Days used the sacrifices of the Great War as a symbol of the sacrifices made in all wars; a development which mirrored the Canadian Remembrance Day commemorations held on 11 November. In his radio announcement of the Memorial Day events in 1971, Grohovaz underscored the word tutte (all) in "all wars" to show that this was no longer simply about the Great War. ${ }^{71} \mathrm{~A}$ more universal approach to the ceremonies allowed Grohovaz to involve Canadian military representatives. This change in emphasis was evident in 1971, when the 4 November celebrations also included a squad of Canadian soldiers alongside the Alpini and other Italian veterans' associations. In his introduction to the ceremonies, Grohovaz prayed that the lives lost in the Great War and all the wars since then would lead to an era of peace: "The sacrifice of so many human lives should be the starting point for understanding between peoples and will push them to finally reflect and love each other." 72 Later in the address, Grohovaz mentioned the tradition of some Great War veterans in Italy meeting in Assisi "in that city of the most Italian and holy of the saints and the most holy of Italians, Saint Francis, Patron of Italy, the saint of peace, of poverty, and of love between peoples." 73 Patriotic invocations to Italy and to the nobility of the Italian soldier are still present in 1971, but they are not emphasized.

world wars, emphasizing the sacrifice of young men while glossing over the historical issues, found its best expression in Donald Brittain's documentary Fields of Sacrifice made for the National Film Board of Canada in 1964. See http://www.nfb.ca/film/Fields_of_Sacrifice/

71 NAC, GF, vol. 1, file 7, Editorials to CHIN.

72 "Il sacrificio di tante vite umane sia principio d'intesa fra tutti i popoli della terra e li spinga finalmente a riflettere e ad amarsi." NAC, GF, vol. 3, ItaloCanadian Club-Veterans' Day Ceremonies.

73 "Nella Città del più Italiano dei Santi e del più Santo degli Italiani, San Francesco, Patrono d'Italia, il Santo della Pace, della Povertà, e dell'Amore tra i Popoli.” NAC, GF, vol. 3, Italo-Canadian Club - Veterans' Day Ceremonies. 
Rather, Grohovaz sees in the Italian culture a tradition of civility and peace. ${ }^{74}$ "The true soldier," wrote Grohovaz "fights for an ideal, without harbouring hate in his heart; he knows that the enemy he is facing is also fighting for the defence of his country: both are fighting for a noble aim, both are worthy of respect." 75

The idea that all soldiers are deserving of respect reflected Grohovaz's desire to turn Memorial Day into a joint Italian and Canadian remembrance. Reaching out to Canadian veterans was not, however, without its complications. Although the two countries had been allies in World War I, the more recent memory of World War II remained an obstacle to mutual understanding. On 4 November 1971 a group of Alpini veterans laid a wreath at the Cenotaph in front of Toronto's Old City Hall only to have it thrown onto the Queen Street tramlines by the Canadian sentries. Grohovaz recounted this story ten years later on CHIN radio with some bitterness, noting that some Canadian veterans failed to understand that "the war is over." 76 This was another example of hostility towards ItalianCanadians, a fact made more painful because it was committed by war veterans: "(Canadians) don't realize that our veterans when they try to render homage to the Fallen place two flowers in front of the monument, one for our dead and one for theirs. These eternal warriors (the Canadians who rejected the gesture) don't understand that death does not separate, rather it unites." 77

After the incident of 1971, Grohovaz became determined to emphasize the bonds that united Italians and Canadians, the shared sacrifice and death in the trenches of the twentieth century's wars. This theme was given its ultimate expression in the last play that Grohovaz wrote for the Memorial Day festivities, From Flanders Fields to the Italian Alps, performed on 4 and 11

74 Here, Grohovaz was identifying with what Robert Harney calls the "great tradition" of Italian culture used by "ethnonationalists" like Grohovaz's friend and mentor Arturo Scotti in the 1950s as a means of fostering a united Italian identity among immigrants. See Harney, "Undoing the Risorgimento," 118-119.

75 "Il vero soldato lotta per un ideale, senza covare odio nel suo cuore; egli sa che il nemico che gli sta di fronte lotta per la difesa della sua Patria: entrambi combattono per un nobile scopo, entrambi son degni di rispetto." NAC, GF, vol. 3, Italo-Canadian Club - Veterans' Day Ceremonies.

76 Grohovaz, ...e al microfono, p. 142.

77 "Non sanno che i nostri, quando si recano a rendere omaggio ai Caduti, davanti al monumento essi posano due fiori, uno per i nostri ed uno per loro. I guerrieri di sempre non sanno che la morte non separa, ma avvicina.” Grohovaz, ...e al microfono, p. 142. 
November 1975. In order to make clear the play's intentions the dialogue was in both English and Italian and the play was performed on the occasion of both Italian Memorial Day and Canadian Remembrance Day. Grohovaz would later claim that this was the first example of bilingual theatre in Canada. ${ }^{78}$ The performance reunited Grohovaz's favourite representatives of Italo-Canadian culture, Mesaglio's Piccolo Teatro and the Coro Santa Cecilia now conducted by Giuseppe Macina. The poster for the event, produced in both English and Italian, shows two paintings of Canadian and Italians soldiers in action during World War I.

The program for the performance announced the concerto as an "anthem for peace which rises from a typical World War I trench in order to reach all those who believe in the co-existence of peoples."79 The fact that the setting was described as any trench indicates how far Grohovaz had strayed from the more historically accurate references of the earlier Memorial Day dramatizations. Depicting an improbable event, the encounter between a young Canadian captain and the lieutenant of an Alpini brigade this play was more allegory than history. The meeting takes place in a mythical space somewhere between the Western Front (Flanders) and the Alpine Front in Italy.

The performance, like the poster, maintained the romantic view of World War I without the D'Annunzian overtones. According to the program of the event, held first at Brandon Hall and then a week later at the Canadian Forces base at Downsview in Toronto, this was the last war fought by "anonymous and unknown heroes." 80 "Today" the program continued, "war is something de-humanizing which knows no values or heroism." ${ }^{11}$ Mario Isnenghi has argued that this idealization of World War I was common among some Italians who, like Grohovaz, had suffered through the trauma of World War II: "The Second World War transformed the First into a remote 'other war.' The Great War was now seen in a different light: it was humanized, and seemed more understandable and justified." 82 Enveloping the Great War in nostalgia was also a way of downplaying the fact that in World War II Canada and Italy had been enemies.

\footnotetext{
78 Grohovaz, "A Quest for Heritage”, 55.

79 Grohovaz, Coro Santa Cecilia, p. 60.

80 Grohovaz, Coro Santa Cecilia, p. 60.

81 Grohovaz, Coro Santa Cecilia, p. 60.
}

82 "La seconda guerra mondiale trasforma la prima in una remota 'altra guerra'. Ottiene tuttavia anche un altro esito: la umanizza, la rende per comparizione più comprensibile e giustificata." Isnenghi, “La Grande Guerra," 306. 


\section{Conclusion: The Limits of Brotherhood}

The dual celebration of 1975 would be Grohovaz's last. After 15 years, Grohovaz left the directorship of the ICRC and, with it, the Memorial Day celebrations. That year also marked the end of Grohovaz's hopes that his hometown of Fiume would rejoin Italy - the Italian government signed the Treaty of Osimo with Yugoslavia that, briefly put, put an end to any Italian claims on the city. The dream that one day Fiume would go back to Italy was always part of Grohovaz's personal vision for Memorial Day, but now it was gone. The year before, Grohovaz had noted that even among the exiled community of Fiumani in Italy the desire to keep political pressure on the Italian government to get Fiume back had vanished. Attending the Congress of Fiumani in Rome in September 1974, Grohovaz was left disillusioned by his fellow exiles. In a series of letters written to other exiles upon his return to Canada, Grohovaz expressed disappointment: "The Fiumani always agree on one vital issue: the symphony of eating and drinking." 83 Most of all, young people no longer seemed to be interested in the culto di Fiume.

Grohovaz's disappointment with the Congress was indicative of the many changes that the Fiuman community in Italy, and Italy itself were experiencing by the mid 1970s. The Congress had been held in Rome's EUR suburb, where a camp for Fiuman refugees had been established after the war. This was one of several camps in which Grohovaz had lived in the mid 1940s. By 1975, the camp was gone, but the community, which included Grohovaz's mother, was still there and living in what was now called the Quartiere Giuliano Dalmata. The neighbourhood had become a site of memory for Fiuman and Istrian exiles. It also boasted a museum dedicated to Fiume's history. The community was now settled and the desire to regain Fiume had changed into nostalgia for something that was irretrievably lost. This is clearly reflected in the letters Grohovaz received about his book of poems in Fiuman dialect. All of them demonstrate a sentimental nostalgia for Fiume stripped of any irredentist hopes. The Treaty of Osimo seemed to confirm the end of irredentism, a fact which Grohovaz accepted with much bitterness. ${ }^{84}$

After 1970 Italy itself had also changed, as represented by its promotion

83 "Il viaggio a Roma è stato una delusione perchè i fiumani sono sempre concordi solo su un punto vitale: la sinfonia del magna e bevi." NAC, GF, vol. 1, file 13, Correspondence about his book.

84 Eisenbichler, "Before the World Collapsed Because of the War," 9. 
of regionalism. Grohovaz's own career reflected this regionalist shift. From 1976 to the end of his life Grohovaz devoted much of his time writing histories of regional associations including the Famee Furlane, and the Club Sanquirinese. Grohovaz's hopes that his vision of unity and patriotism would have echoes in Italy were gone by the mid-1970s. Doubtful as well was the impact of the Memorial Day festivities on Italians in Toronto. It is not known how well attended the Memorial Day celebrations were within the Italian community. Grohovaz was certainly proud of his achievements and his ability to have the participation of the Italian ambassador, consul, and representatives of the armed forces was a testament to his abilities as an organizer. The collaboration of the Piccolo Teatro and Coro Santa Cecilia no doubt attracted many to the celebrations, as both groups were well known and respected in the community and also back in Italy.85 Also, Il ragazzo del '99 was filmed and shown on Italian-Canadian television during the Memorial Day weekends, giving it a potentially wider audience.

Despite this renown, however, it is doubtful whether Grohovaz's productions had much impact beyond the veterans' associations. This was not for lack of quality, but for the largely personal vision they embodied and for the attempt to graft a united identity on Toronto's Italians, something which Robert Harney has shown to have been a difficult enterprise throughout the history of Italian settlement in Toronto. ${ }^{86}$ The patriotic key of Grohovaz's productions, with their use of Alpini tropes and D'Annunzian language, which conformed to Grohovaz's own experiences as a veteran in the elite regiment and as a citizen of Fiume growing up in the shadow of the poet's takeover of the city, did not resonate either among Toronto's Italians or in Italy itself. This had much to do with Fascism's appropriation of the patriotic D'Annunzian vision between the wars. ${ }^{87}$ Grohovaz was not a fascist, an ideology he denounced as one of "dubious morality", but in the minds of many Italians an overtly patriotic image of World War I which indulged in irredentist imagery carried too many reminders of Mussolini's regime. 88 This association with fascist rhetoric

85 The Piccolo Teatro was awarded a "Leone d'oro" by the City of Venice in 196162. See Bancheri/Pugliese, "Italian Theatre?" 86.

86 Harney, "Undoing the Risorgimento," 114.

87 On the appropriation of D'Annunzio's Fiume expedition see Gumbrecht, "I redentori della vittoria." On Mussolini's copying of D'Annunzio's political style, see Ledeen, The First Duce.

88 Grohovaz stated his position on Fascism during a CHIN radio broadcast in 1971. NAC, GF, vol. 1, file 6, Editorials to CHIN. 
was not just a problem in Italy, but also affected Toronto's Italians. John Zucchi has demonstrated how the Italian consulate in the 1930s tried very hard and failed to instil a fascist unity on the city's Italians, especially in ceremonies commemorating 4 November. ${ }^{89}$

More than just the fascist appropriation of D'Annunzian language, Grohovaz's efforts were also limited by their attempt to impose what Nicholas Harney has called a "monumental" narrative on Italian-Canadian identity which "produces a selective and illustrious representation of the past." 90 The memory of World War I, as presented in Grohovaz's productions, was of a nation united in a patriotic cause, but this did not conform to the reality of Italy's response. Italy was a divided country in 1915-1918 and the war was generally unpopular. As we have seen, Grohovaz adopted a romanticized vision of that war, which not only reflected his own identity as a Fiuman, but also tended to obscure the much more problematic experience of World War II. The result was a picture of the war that did not necessarily reconcile with many Italians' recollections of that war and also seemed to attempt what many others had failed to do: graft a narrative of national unity on Toronto's Italians.

With the last of the ICRC performances of Italian Memorial Day, Grohovaz retreated into a more intimate remembrance of 4 November. From 1976 to 1987 Grohovaz shared the day with his fellow Alpini at the new Alpini monument erected on the grounds of Toronto's Columbus Centre. For Grohovaz this monument was personal, as it contained a vial of Fiuman soil. ${ }^{11}$ Grohovaz's retreat into this more intimate and private celebration of 4 November and away from community activism was partly due to health reasons and to the fact that he had accomplished what he set out to do, albeit with some disappointments. In one of the last interviews he gave in his life, he told Claudio Antonelli that he had suffered much disillusionment in his attempts to unify Italian-Canadians. ${ }^{92}$ In some ways, the monument was a fitting tribute to Grohovaz's 4 November celebrations since it was located on the grounds of the institution that had largely replaced the old Brandon Hall and the by-now defunct ICRC. The Columbus Centre, which opened in 1976, was, according to Nicholas Harney, designed as an indoor town with a piazza in order to foster an

89 The pro-fascist consulate specifically exerted extensive pressure on the war veterans' groups in Toronto. See Zucchi, Italians in Toronto, 172-173.

90 Demaria Harney, “Ethnicity, Social Organization, and Urban Space," 194.

91 Eisenbichler, "'Before the World Collapsed Because of the War", 3.

92 Antonelli, Fedeli all'Istria, pp. 85-6. 
ambiente that would allow Toronto's Italians to become a community rather than just a settlement. ${ }^{93}$ Here, Grohovaz's experience as war veteran and exile could be expressed in a new space dedicated to the forging of a united Italian community.

Ave Maria University, Florida

\section{CITED WORKS}

\section{Manuscript Sources}

National Archives of Canada (NAC), Grohovaz fonds (GF)

vol. 1, file 4: Employment at the Public Archives

vol. 1, file 6: Editorials to CHIN.

vol. 1, file 7: Editorials to CHIN.

vol. 1, file 12: Correspondence about his book.

vol. 1, file 18, Il ragazzo del '99.

vol. 1, file 17: Il dono del vecchio soldato.

vol. 1, file 21: Correspondence about his book.

vol. 2: Associazione Nazionale Alpini.

vol. 3: Italo-Canadian Club-Veterans' Day Ceremonies.

Grohovaz, Gianni. "Rimestando tra le acque del passato. Forse trent'anni fa era più facile." Unpublished talk delivered at the Italian Club, Erindale College, University of Toronto, 8 February 1984. Author's autograph in the collection of Prof. Robert Buranello.

\section{Printed Sources}

Antonelli, Claudio. Fedeli all'stria, Fiume, Dalmazia. Noi, profughi emigrati. Montreal: Lòsna \& Tron, 1997.

Bancheri, Salvatore and Guido Pugliese. "Italian Theatre" in Julius Molinaro and Maddalena Kuitunen (eds.), The Luminous Mosaic: Italian Cultural Organizations in Ontario. Lewiston NY: Editions Soleil, 1993, pp. 79-104.

Buranello, Robert. " 'Chi mai gavessi deto: The Immigrant Experience in Giovanni Angelo Grohovaz's Strada Bianca" in Konrad Eisenbichler (ed.) An Italian Region in Canada. Toronto: Multicultural History Society of Ontario, 1998, pp. 137-151.

Demaria Harney, Nicholas. "Ethnicity, Social Organization, and Urban Space: A Comparison of Italians in Toronto and Montreal" in Johanne Sloan (ed.), Urban Enigmas: Montreal, Toronto, and the Problem of Comparing Cities. Montreal: McGill-Queen's University Press, 2007, pp. 178-212.

93 Nicholas De Maria Harney, "Columbus Centre: A Piazza of Italian Canadian Identity," in Molinaro and Kuitunen (eds.), Luminous Mosaic, 65-67. 
Eisenbichler, Konrad. "I Giuliano-Dalmati in Canada." Italian Canadiana 9 (1993): 31-45.

. "Un fiumano d'oltreoceano: Gianni Angelo Grohovaz." La Battana 160 (April-June 2006): 103-120.

"Il ricordo del paese natale nelle opera di scrittori giuliano-dalmati emigrati in Canada." Ateneo Veneto 194, terza serie 6:1 (2007): 97-113.

" 'Before the World Collapsed Because of the War': The City of Fiume in the Poetry of Gianni Angelo Grohovaz." Quaderni d'italianistica 28:1 (2007): 115-134.

Franzinelli, Mimo. "L'8 settembre" in Mario Isnenghi (ed.), I luoghi della memoria. Personaggi e date dell'Italia unita. Bari: Laterza, 1997, pp. 241-270.

Grohovaz, Gianni Angelo. Per ricordar le cose che ricordo. Poesie in dialeto fiuman.

Toronto: Casa Editrice Dufferin Press, 1974; $2^{\text {nd }}$ ed. 1976.

. “Toronto's Italian Press after the Second World War.” Polyphony 4:1 (1982): pp. 105-113.

_...e con rispetto parlando è al microfono gianni grohovaz. Diario radiofonico, quasi settimanale, di un italiano in Canada, 1980-1981-1982. 74 editoriali radiotrasmessi dalla CHIN, stazione radio internazionale di Toronto, Ontario, Canada. Toronto: La Casa Editrice Sono Me, 1983.

. "A Quest for Heritage: Piccolo Teatro Italiano.” Polyphony 5:2 (1983): pp. 47-56.

—. "See You at Brandon Hall. Oh!...I Mean the Italo-Canadian Recreation Club.” Polyphony 7:2 (1985): pp. 98-104.

Coro Santa Cecilia: Toronto, Canada, 1961-1986. Toronto: Toma Publishing Co., 1986.

. Strada Bianca. Dall'estrema sponda dell'Adriatico alle diecemila cattedrali dell'Ontario. Toronto: La Casa Editrice Sono Me, 1989.

Gumbrecht, Hans Ulrich. "I redentori della vittoria: On Fiume's Place in the Genealogy of Fascism.” Journal of Contemporary History 31:2 (1996): 253-272.

Harney, Robert. "Undoing the Risorgimento: Emigrants from Italy and the Politics of Regionalism" in Robert Harney (ed.), From the Shores of Hardship. Lewiston NY: Soleil, 1993, pp. 105-131.

Iacovetta, Franca. Such Hardworking People: Italian Immigrants in Postwar Toronto. Montreal: McGill-Queen's University Press, 1992.

Isnenghi, Mario. Il mito della Grande Guerra. Bologna: Il Mulino, 1989.

. "La Grande Guerra" in Mario Isnenghi (ed.), I luoghi della memoria. Strutture ed eventi dell'Italia unita. Bari: Laterza, 1997. pp. 273-310.

Ledeen, Michael. The First Duce: D'Annunzio at Fiume. Johns Hopkins University Press, 1977.

Oliva, Gianni. "La Naja” in Mario Isnenghi (ed.), I luoghi della memoria. Strutture ed eventi dell'Italia unita. Bari: Laterza, 1997, pp. 95-109.

Shipley, Robert. To Mark Our Place: A History of Canadian War Memorials. Toronto: NC Press Limited, 1987.

Zucchi, John. Italians in Toronto: Development of a National Identity, 1875-1935. 
Kingston and Montreal: McGill-Queen's University Press, 1988.

"Cultural Constructs or Organic Evolution? Italian Immigrant Settlements in Ontario," in Julius Molinaro and Maddalena Kuitunen (eds.) The Luminous Mosaic: Italian Cultural Organizations in Ontario. Lewiston NY: Editions Soleil, 1993, pp. 19-37. 